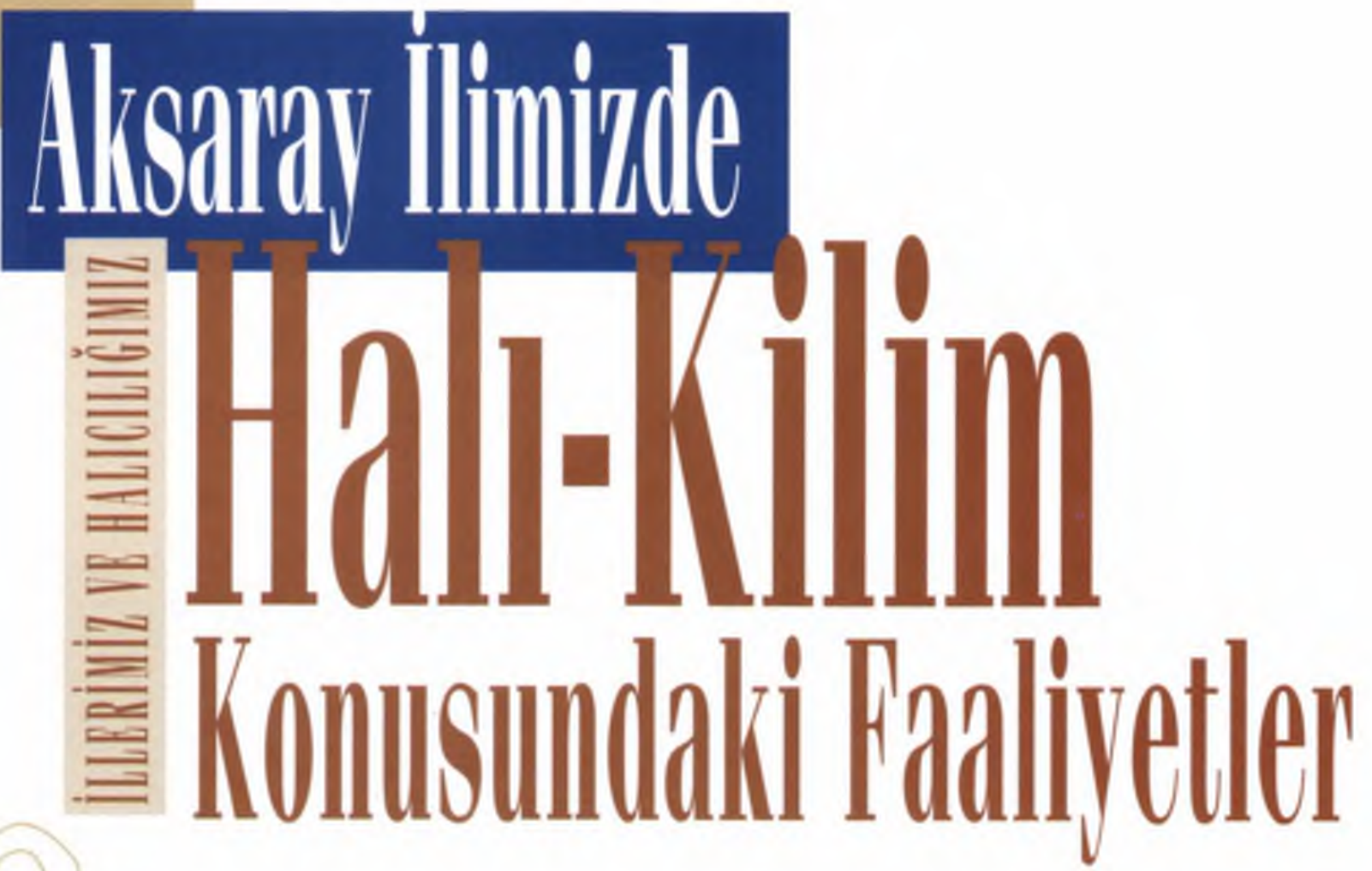

Selçuklular devrinde beyaz mermerden bir saraya nispetle (Aksaray) adını aldığı söylenen en genç illerimizden Aksaray zengin bir tarihe sahiptir. Cumhuriyet Devrine kadar gelen, Aksaray Kuva-i Milliye'ye iştirak eden Kurtuluş Savaşımızda üzerine düşen vazifeleri hakkıı ile yapmıştır.

Aksaray sınırları; doğuda Nevşehir, batıda Konya'nın Bozdağları, güneyde Karacadağ, kuzeyde Ankara ve Kızlırmak'la çevrilmiştir. Yüzölçümü 7626 kilometrekare olup, nüfusu 1990 sayımına göre 90 bini aşmıştır.

Aksaray iline bağı 7 ilçe, 35 belediye teşkilatı, 160 köy mevcuttur.

Aksaray; tarihî kaynaklara göre daima büyük bir ilim ve ticaret merkezi olmuş, çok mühim ve zengin bir bölgedir. Adana'yı Ankara'ya, Kayseri'yi İzmir'e bağlayan yollar üzerinde olan iktisadî ve ticarî bir şehirdir. Aksaray'ın günden güne gelişen halıcılık, çiftçilik, hayvancılık, kavakçllk bakımından bir istihsal merkezi oluşu, gelişen sebze ve meyveciliği de sevindiricidir. İlimiz yeraltı madenleri ve petrol bakımından ümitli olunan saha içindedir.

Aksaray, İslamî devirlerin il merkezi olarak görülmüş, sultanların, vezirlerin zaman zaman ikamet ettiği ve büyük âbideler, saraylar yaptırdığı yer olmuştur. Aksaray camileri, minareleri, medreseleri, hanları, türbeleri saymakla bitmeyen eserleri ve sayısız ziyaretgâhlarıyla bir evliyalar diyandır.

Türk-İslâm kültürü içinde halı, toplumun estetik duyuş ve görüşlerinin yansıdığı alanlardan biridir. Düğümlü ilk halılar Orta Asya'da Türkler tarafından dokunmaya başlanmıştır. Bu durum gelişmiş bir teknolojinin habercisidir.

Ibn-i Batuta kitabında "Aksaray halılarnnın ilk kaynağı Tokarız ve Taşpınar'dır" der. Renklerinin solmazlığ 1 ile meşhur halıların Suriye, Irak, Mısır, Hindistan, Çin ve Türk ülkelerine ihraç edildiğini yazar.
Her yeni halı tipi bir öncekini aşarak yeni ve zengin bir örneğin meydana gelmesini sağlamıştır. Köklü bir gelenek ve yaratıcı bir gücün üstünlüğü ile zengin bir çeşitlilik kazanmıştır. Bu gelenekli sanatın yaşatılması için Aksaray Valiliği, halıcılık atelye faaliyetlerini hızlandırmıştır.

Aksaray'ın Hasan Dağı, Bayıraltı ve Ova köylerinde yaşayan 14-50 yaş arasındaki kadınların çoğu hah dokumacılı̆̆ı ile uğraşmaktadır. Yörede 7 çile olarak adlandırılan ortalama 2,3-5 metrekarelik bir halı iki kişi tarafından 15 günde dokunmaktadır. Karşılığında dokuyucular 20 milyon civarnnda ücret almaktadırlar.

İlimizde $3000^{\prime}$ e yakın kişi halı,kilim üretiminde ve onarımında çalışmaktadır. Karşıılığında yaklaşık 200 milyar civarında ücret ödenmektedir. Yurtdışına metrekaresi 150200 dolardan satılan bu halılarla yurda 4-5 milyon dolar döviz girdisi sağlanıyor.

Halıcılıkta Aksaray'ın birçok köylerinde gelişme potansiyeli görülmektedir. Mevcut potansiyeli değerlendirmek amacı ile Aksaray Valiliği, ürün kalitesi ve standardizasyon kolunun geliștirilmesi, üreticilerin ihtiyaçlarını sağlama, üretim pazarlama sürecini en iyi sonuçlara ulaştıracak bir yapılanmanın gerçekleştirilmesi çabasindadır.

A, Iliniz hudutlar içinde:

a) Hal, kilim üretiliyor mu?

1. Yaklaşık kaç metrekare halı/kilim üretiliyor?

İlimizde yaklaşık 30.000 metrekare halı üretilmektedir. Aksaray yöresinde kilim üretimi hemen hemen yok denecek kadar azdır. Unutulmaya yüz tutmuş bu geleneği canlandırmak ve sürdürmek için Aksaray Valiliği kurs düzenleme çalışmalarını başlatmıştır. Kilim desenlerinin 


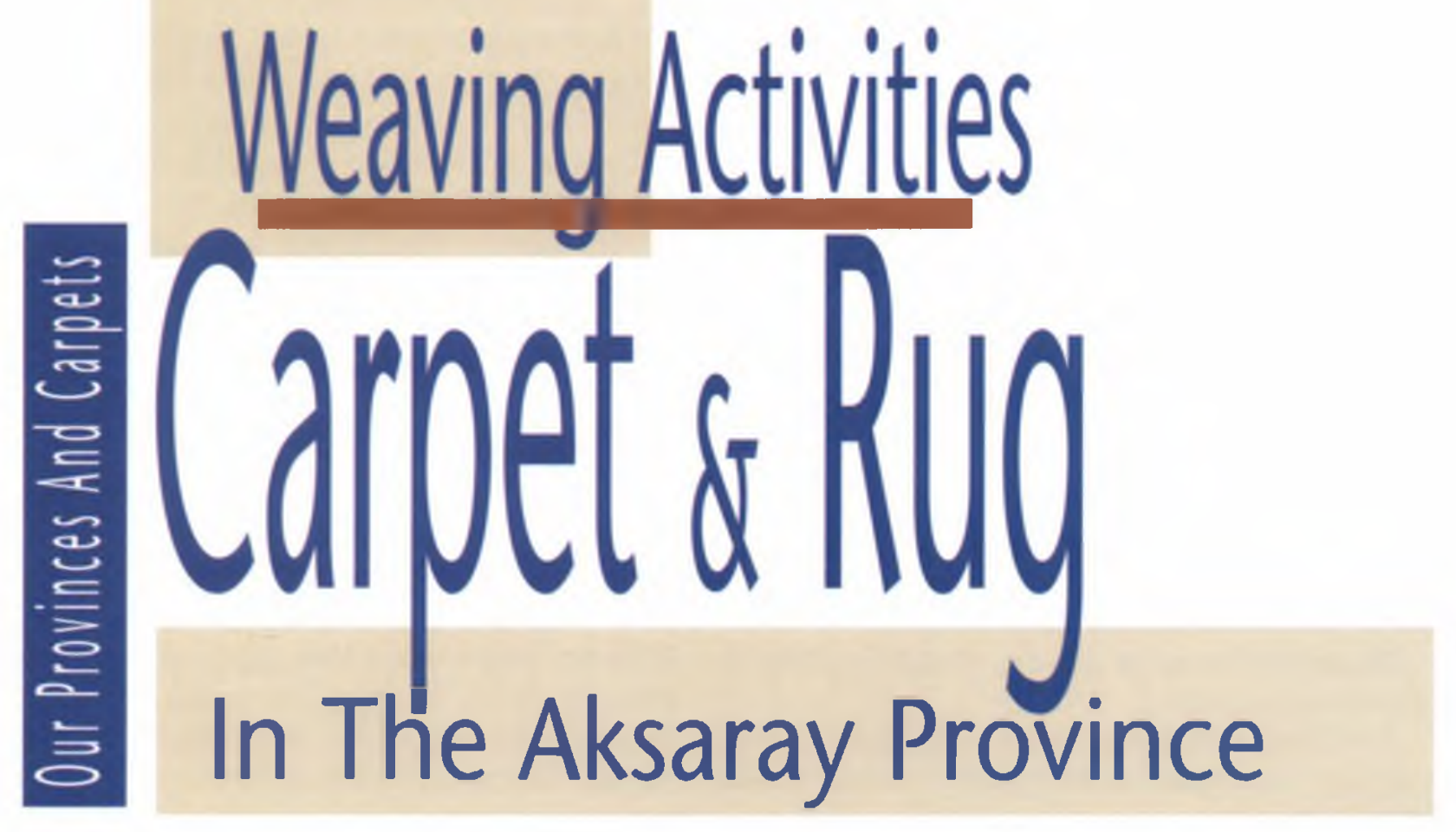

Aksaray, one of our youngest provinces, reported to be sp named because of a selchukite palace made of white marble, has a rich history culminating in an outstanding participation to the Independence War within the national forces.

The province is bordered by Nevşehir in the east, Bozdağ range of Konya in the west, Karacadağ in the south, and Ankara and Kızilırmak in the north. It has a surface area of 7.626 square kilometers and a population of over 90.000 according to the 1990 census.

Aksaray has today 7 sub-prefectures, 35 municipalities and 160 villages.

Aocording to the historical records, this well-endowed province had always been a major centre of education and trade due to the fact that it is situated on the crossroad of Adana-Ankara and Kayseri-Izmir highways. The carpet-weaving, farming, animal breeding and poplar orchards plus its developing horticulture gives this province a rather bright prospect supported by the fact that it is one of the promising oil exploration districts.

Aksaray was a provincial seat throughout the administrations with a religious tinge and a city where the sultans and viziers have erected beatiful manors, monuments and palaces. Its mosques, minarets, theology schools, inns and shrines make it truly a region of saints.

The carpet in the Turkish-Islamic culture is an object into which are reflected the aesthetic feelings and opnions of the society. A developed weaving technology, achieved by the Turkish tribes in Central Asia, heralds a turning point in this art.

Ibn-i Batuta's book states that "The origins of Aksaray carpets may be traced back to Tokariz and Taspinar" and adds that the non-fading features of these carpets had made them renowned in the other Turkish States as well as in Syria, Iraq, Egypt, India and China to which they were exported.

Each new type of carpet, exceeding the preceding one, has led to a newer and richer pattern, acquiring thus a rich variety backed by a proven tradition and a crative mind. The Aksaray Governorship increased and enhanced its support to the workshops where carpetweaving has traditionally continued.

Many women between fourteen and forty years of age living in Hasandağı, Bayıraltı and Ova villages of Aksaray are involved in carpet-weaving. A carpet of $2^{1 / 2}$ to 3 square meters, referred to as "seven hanks" in the region, is woven in about two weeks by two weavers who receive roughly twenty million Liras for their toils.

There are around 3.000 thousand people working in the field of carpet and rugh production and repair, and receiving about 200 billion Liras per annum. A foreign currency input of 4 to 5 million Dollars is the rsult of exports commanding a price of 150 to 200 Dollars per square meter.

A significant carpet-weaving development potential exists in many villages of Aksaray where the provincial authorities strive to develop the product quality and standardisation, to meet the needs of weavers and to establish a system for radically improving the marketing process for a better evaluation of the current potential.

A) Within your province

1. Are carpets and rugs woven?

a) Approximately how many square meters?

The annual production is about 30.000 square meters. Rug production is almost nonexistent in Aksaray region. Courses are scheduled by the provincial authorities to revive and maintain this art which is at the near-oblivion 
günümüze kadar gelebilen örnekleri halk arasında "Makat kilimi" diye bilinen büyük kilim, yine yörede "Toplu ve fardalı kilim" diye bilinen yanyana üç veya dört göbekli süslü kilimlerdir. Kutlu Köyü'nün yaylacılık yaptığı dönemlerden kalmıştır. Kilimlerde yaygın olarak "Eli belinde" motifine rastlanmaktadır.

2. Yaklaşık kaç metrekare halı/kilim dış pazarlara ulaştırlabiliyor?

İlimizde üretilen halılann büyük bir bölümü yurtdışına pazarlanmakta, özellikle Almanya ve A.B.D.'ne ihraç edilmektedir.

b) Halı üretimi ile ilgili:

1. Fakülte veya Yüksek okul var mı? Il yönetimi olarak bu ögretim kurumlar ile halk arasında olan ve olmasi gereken ilişkilerde hangi rolleri üstleniyorsunuz? Hangi rollerin üstlenilmesi gereğine inanıyorsunuz?

Illimizde halı üretimi ile ilgili olarak Fakülte veya Yüksek Okul bulunmamaktadır.

2. Düzenli halı kursu var mı? Nerededir? Hangi periyotlarla düzenleniyor ve kimler katılyor? Hangi kuruluş düzenliyor?

Aksaray Valiliği ve özel şirketler işbirliği ile merkez kasaba ve köylerde öğretim yılı itibariyle 1000 saat süreli halı kurslanı açılmaktadır. Bu kurslarımıza 14-50 yaş grubu arası kursiyerler katılmaktadır.

3. Üretim kooperatifi veya vakıf yahut satıs birliği türünde örgüt var mi?

Ilimizde üretim kooperatifi veya vakıf yahut satış birliği gibi örgüt türlerine rastlanmamaktadır.

4. Pazarlama konusunda hangi türden oluşum ve girişimler var?

Pazarlama konusunda, halı şirketleri anlaştıklanı özel ihracaatçı firmalar aracılığı ile dokunan halıların dış pazarlarda satılmasını sağlamaktadırlar. Bu ihracaatçı halı firmalarının piyasadan aldıkları taleplere göre motif ve desen çalışmaları değişmektedir.

5. Daha önceki yıllarda pazarlamaya dayalı bir çalışma yapild $m \imath$ ?

Ilimizde Salı günleri halı pazarlan kurulmakta ve burada yöreye özgü el dokuması halılar sergilenerek pazarlaması yapilmaktadir.

6. Fuar, panayır, kermes türünden sergi/pazarlama faaliyetleri var mı?

Milli Eğitim Bakanlığı'nca bölgeye özel düzenlenen fuarlarda yöremize özgü el dokuması halılar sergilenmekte ve büyüik ilgi görmektedir. Valiliğimizce düzenlenen halı sergilerinde, halkın bilinçlendirilerek istihdama yönelik ve üretimi teşvik edici çalışmalar hedeflenmektedir.

7. Halı/kilim ihracaatçlarnın bölge üreticilerinden sekil, boyut, renk ve motif konularnda özel istekler ve yönlendirici talepleri oluyor mu?

Halı ihracaatçılan, bölge üreticilerinden gelen talepler doğrultusunda, desenleri sipariş olarak alır veya kendi desinatörlerine çizdirerek üreticiye verirler. Günümüzde geometrik desenlerden daha çok bitkisel desenler yoğunluk kazanmıştır. Bitkisel desenler üsluplaştırılarak verilir. Hayvan figürlerine de rastlanır. Daha çok kuş figürleri stilize edilerek işlenir. Günümüzde "Kayseri Empirme Modeli" dahil her tür desen kullanılmaktadır. Son yıllarda manzara tasvirleri de kullanılır olmuştur.

Halk arasında "Taban" halısı ismiyle anılan yaklaşık $3.10 \mathrm{x} 4.20 \mathrm{~m}$. ölçülerindeki halılar özel olarak, istek üzerine üretilmektedir. Günümüzde daha çok $2.30 \times 1.20 \mathrm{~m}$. ölçülerinde halk arasında "Göbekli halı" ismiyle anılan seccâdeler iç ve dış piyasalarda pazarlanmaktadır. Son yıllarda yöremizde dokunan Azerî tipi halılara da büyük talep vardir.

B- Iliniz hudutlan içindeki halllar:

a) Tarihî bakımdan adlandırılabilme ve tarihlendirilebilme özelliklerine sahip midir?

Geçmiş araştırıldığında dokuma namazlıklar en eski örnek olarak karşımıza çıkmaktadır. Bugün Aksaray Müzesi'nde teşhir edilen 4 tane halı mevcuttur. Bunlardan birinci örnek 18. yüzyıldan kalmadır. İkinci örnek Aksaray çevresinde 13. yüzyılda dokunmuş olmalıdır. Üçüncü halı Aksaray yöresinin "Yatak Halıları"nı andıran modelidir. 18. yüzyıllarda dokunmuştur. Aksaray geleneklerini taşıyan dördüncü halı ise 19. yüzyl eseri olarak tarihlendirilmiştir.

1. Hangi tarihlerden beri, hangi köy ve kasabalarda halı ve kilim üretiliyor?

Orta Asya'da başlamış bu Türk halı dostluğunun bugün Anadolu'da hâlâ devam ettirildiği pekçok noktadan birisi de Aksaray yöresidir. Aksaray, Selçuklular devrinden beri ünlü bir halı merkezidir. Bu gelenek Osmanlılar devrinde de sürmüştür. Günümüz halıları adını verdiğimiz 1950 yıllarından beri devam eden Aksaray yöresi halıları, Aksaray'a bağlı "Ova köyleri" Armutlu, Yenikent, Eskil, Eşmekaya, Kutlu Köyü, Sultanhanı, Yeşilova; "Bayıraltı Köyleri" Altınkaya, Ulukışla, Yeşiltepe; "Hasandağı Köyleri Elmacık, Koçpınar, İncesu, Karataş, Gözlükuyu Taşpınar Kasabası'nda dokunmaktadır. Dokunan bu halıların hammaddesi yündür. Doğal boya, kök ve sentetik boya karıştırılarak renkler uygulanmaktadır.

2. Bunların motif, yanıs, nakıs adı verilen bezemelerine sizin bulunduğunuz il hudutlar içinde yöreye has adlar veriliyor $m u$ ?

Aksaray yöresi halılarında günümüze kadar gelen en eski yanış "üç göbekli halı" bezemesidir. Günümüz Taşpınar Halısı desenleri özgün bir karaktere sahiptir. Desenlerin büyük bir bölümünün nasıl or taya çıktığı bilinmemektedir. Aksaray yöresi halıları "Taşpınar Halısı" ismiyle tanınmaktadır. Anadolu'da halıcılık, köklü geçmişi, ilmek ilmek dokunduğu, atılan her düğümle geleneklerin günümüze taşındığı özgün el sanatının hâlâ devam ettirildiği Aksaray yöresindeki Taşpınar Kasabası'ndadır.

Taşpınar Halılarının günümüze değin titizlikle koruduğu özelliklerinden bir tanesi atkı, çözgü ve düğüm iplerinin tamamen yün olmasıdır. Kaliteyi belirleyen bir öğe de düğüm sayılarıdır. Eski Taşpınarlar'da 10x10 santimetrekarelik alanda $40 \times 45$ düğüim vardır. Günümüzde elle eğirilmiş iple dokunan bir halıda $10 \times 10$ 
stage. Among the pattern samples which survived to our day are the large pieces referred to as the "Makat" and those having three or four laterally-arranged medallions, which are called "Toplu" or "Fardalı" and inherited from the times when the Kutluköy village was nomadic. The so-called "hands akimbo" pattern also is quite widespread.

b) Roughly how many square meters penetrate into foreign markets?

A large part of the carpets woven in the province is marketed abroad, especially in Germany and USA.

2. In connection with the carpet and rug weaving

a) Are there faculties or institutes for carpet--weaving? What rule do you assume in the relations which exist or should exist between these educational institutions and the people? Which roles do you believe that should be undertaken?

There are no faculties or institutes teaching this art within our province.

b) Are carpet-weaving courses organised in your province? Where are they located? At which intervals are they held? Who participate to them? Which agency organises them?

Courses for total of 1000 hours per annum are held at the provincial and sub-prefectural seats and in villages through aa scheme of collaboration between provincial authorities and private companies. Trainees are females between 14 to 50 years of age.

c) Are there entities such as production and sales cooperative societies or foundations?

There are no production or sales coöperatives or foundations within our province.

d) What initiatives and enterprises exist for marketing?

Private companies market their carpets abroad through specialised export companies. The carpet patterns vary according to the orders received by export companies.

e) Has marketing work been done in the past years?

Open carpet markets are held every Tuesday in the provincial seat where original hand-woven carpets are exhibited and sold.

f) Are there fairs, exhibitions and auctions?

In regional fairs held within the province are exhibited the original local hand-woven carpets by the Ministry of National Education. Since these fairs have received a country-wide echo, the provincial authorities continuously introduce methods that heavily emphasize the employment-increasing and production-promoting aspects of the trade.

g) Are there special requests and orienting demands from the carpet and rug exporters as to the colour, dimensions, patterns and shapes?

The carpet exporters receive from the weavers the requested patterns as orders, have them drawn by their designers and issue them to the looms. Plant patterns have today a demand greater than that for geometrical shapes and forms. These patterns are stylised by the designers who produce also animal figures which are mostly based on avial forms. In general, all sorts of patterns, including the so-called Kayseri print, are used today. There is a growing demand in the recent past also for scenic patterns.

The "Taban" carpets of $3 \times 10$ and $4 \times 20 \mathrm{~m}$. dimensions are produced on special orders. At the present time, $2.30 \times 1.20 \mathrm{~m}$. prayer rugs, called as "bemedalled", are much sought after both within the country and abroad.

B) Carpets in your province

a) May they be historically named and dated?

A retrospective study show that the woven pray-rugs are the oldest examples that survived to our day. There are four carpets exhibited in Aksaray Museum. The first of which date back to eighteenth century, the second is believed to have been woven near Aksaray in the tghirteenth century, the third is the eighteenth century model called "bed carpet" in the province and the fourth is a product from nineteenth century.

1) Since when and in which towns and villages are carpets produced?

One of the many points in Anatolia where the art of carpet-weaving which was inherited from Central Asia continues to maintain its traditions is the region of Aksaray which is a known carpet centre since the early days of Selchuk Empire which transmitted it to its successors the ottomans. Region's carpets are produced at the so-called lowland villages of Armutlu, Eskil, Eşmekaya, Kutlu, Sultanhanı, Yeniköy and Yeşilova and plateau towns and settlements of Altınkaya, Elmacık, Gözlükuyu, Hasandağı, Incesu, Karataş, Koçpınar, Taşpınar, Ulukışla and Yeşiltepe. Wool is the raw material used in these carpets of which the colours are made up of mixtures of natural and root dyes and synthetic colorants.

2) What local names are given to their models, designs and patterns?

The design most widely-used to date on Aksaray carpets is the trimedalled one. Tasspınar carpets have a characteristic design of their own. Origins of these designs could not be determined in any degree of certainty. Carpets of this region aere known as Tasspınar ones since this town is known to be an important centre of carpet-weaving where the knotting technique inherited from Turkish tribes coming from Central Asia was perfected.

Another feature which has been meticulously preserved in Taşpınar carpets arfe the mexclusive use of woollen yarns in the wefts, warps and knots. Another factor influencing the quality is the number of knots in each $10 \times 10 \mathrm{~cm}$ area. While the old Taşpınar carpets had 40 to 45 knots, the currently woven ones made using hand-twisted yarns contain 30 to 35 . Colours of Taşpınar carpets are obtained with the root dyes. Use of dark red and dark blue for main colours is as muchthe result of fidelity to traditions as of the desire to obtain a serious and decorative effect between the border and main pattern given in the central medallion. 
santimetrekarede 30x35 düğüm görülmektedir. Taşpınar halılarına karakteristikliğini veren, renklerin elde edilmesinde kökboya kullanılmış olmasıdır. Taşpınar'da ana renklerin koyu kırmızı ve koyu mavi olması bir geleneğe bağlılığı gösterdiği kadar halıda bir çerçeve oluşturan bordürlerle ana motifler madalyon düzeni arasında gözü dinlendiren boşluklann ağır başlı, dekoratif bir etki yapmasını sağlar. Taşpınar halılarının tüm çeşitleri geometrik düzende yerleştirilmiş, bitkisel kökenli motiflerle bezelidir. Halıda çerçeve oluşturan bezemenin ilk basamağı olan bordürlerin, iç bordür olarak ikinci kez kullanılması bordür sayısını artırıp, Taşpınar halılarına hareket kazandırarak zenginleştirmiştir.

Taşpınar'ın adlandırılmasında, önemle yeri olan iç bordür gelir. Özgün reng tetir (Tarçın rengi) olan bu bordürün yöresel adı "Ayak"tır. Taşpınar halılarının orta bölümünü oluşturan zemin yüzeyinin bezemesine sandık denilen bölümle başlanır. Sandık, bordürün,halının kısa kenarında meydana getirdiği dikdörtgen çerçeveye verilen addır. Zemin yüzeyinin bezemesinde ikinci aşama olan madalyonu çevreleyerek motifi daha da zenginleştiren "Sütunce" şeklindeki bordüre verilen yöresel ad "Sallama"dır. 10-12 cm. kalınlığında olan sallamalar halı köşelerinde birbirlerine sütun başlıklarını andıran kare şeklindeki dolgularla bağlanırlar. Bunlara "Tuğ" denir. Sallamaların içi gibi tuğlarda geometrik ve bitkisel desenlerle bezenebilir. Zemin yüzeyinin düzenlenmesinde üçüncü aşama köşelerdir. Köşeler, zeminde yer alan ana motifi bordürden ayıran ve halının uzun ve kısa kenarları ile dik açı oluşturan üçgen boşluklardır. Köşe konturlarını iç içe geçmiş dar sular oluşturur; bu sulara "Sızı" denir. Köşelerin zemin rengi laciverttir. Her zaman bitkisel desenlerle süslenmiştir. Zemin yüzeyinin kompozisyonu merkeze yerleştirilen madalyon motifi ile tamamlanır. Yöredeki adı "Göbek" olan madalyon, namazlık dışında tüm Taşpınar çeşitlerinde kullanılmıştır. Bir yüzey süslemesi olan, halıda derinlik duygusu uyandıran, sonsuzluk çağnsı yapan Taşpınar, yarattığı bu etki ile Türk Sanatı'nın genel karakterinden ayrılmadığını gösterir.

b) Iliniz hal, kilim dünyası ile ilgili olarak:

\section{Bă̆ımsız kitaplar}

\section{2. Özgün makaleler}

3. Ansiklopedi maddeleri halinde hazirlanmıs bilimsel çalışmalar yapıldı mı? Yapıldı ise, bibliyografik künyeleri nelerdir?

İlimiz halı kilim dünyası ile ilgili olarak; Taşpınar Tarihi Hk. Bkz. İbrahim H. Konyal1, Abideleri ve kitabeleri ile Niğde Aksaray Tarihi, Ankara 1974, sayfa 2088.

Bekir Deniz, Taspinar Hahlan Örnek Alınarak Kayseri ve Cevresinde Cağglaş Türk Halı Sanatı, A.Ü.D.T.C. Fakültesi basılmamış doktora tezi, tzmir 1981.

Bekir Deniz, "Aksaray Müzesi Halıları" III. Ulusal El Sanatlar Sempozyumu Bildirileri, İmir 23-25 Kasım 1983, Izmir 1984, s. 93-127.

Bekir Deniz, "Taşpınar Halıları", Sanat Dünyamız, 1982, s. 25.

Şerare Yetkin, Türk Halı Sanatı, İş Bankası Kültür Yayınlan, İstanbul, 1974, s. 100.

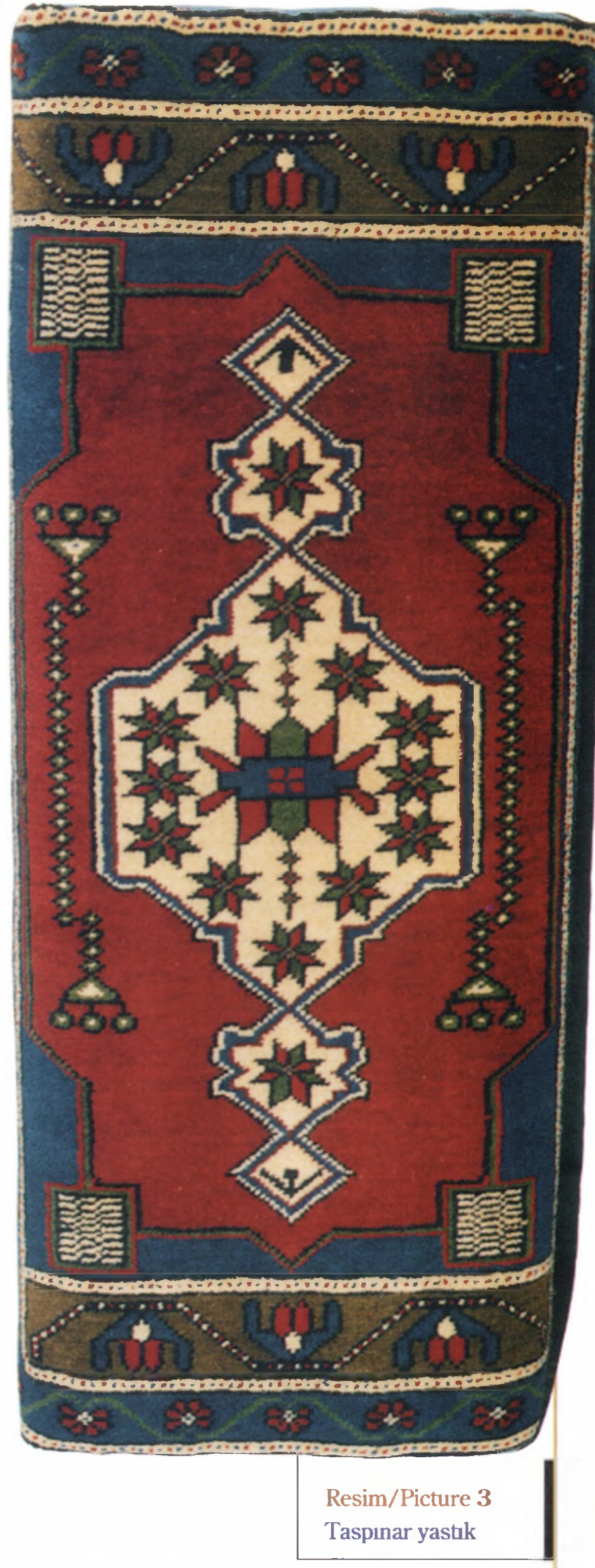

Zeynep Gür, 19. Yüzyıldan Günümüze Taşpınar Halıları, Yayınlanmış Master Tezi, 1982.

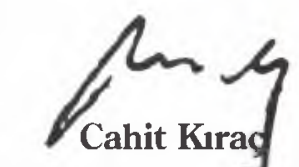

Eski Aksaray Vhlisi 
All individual Taşpınar carpets are decorated with patterns of plant origin placed in a geometrical order. The reuse of these borders constituting the first step of the decorations as the inner ones increased the number of borders and imparted a certain richness and movement to Taşpınar carpets.

The inner border has an important place in the Taşpınar lexicography. The local name of this border which is of cinnamon colour (Tetir) is "Ayak". Decoration of the background forming the central part of a Tasppınar carpet begins with the part called "Sandık" which is the name given to the rectangle created by the border on the shorter side of the carpet. Then comes the border referred to as "Sallama" which encircles the central medallion and enhances the pattern's beauty. The sallamas, having a width of 10 to $12 \mathrm{~cm}$, are connected to each other with square fillers (Tuğs) reminiscent of column heads. Tuğs may be decorated with geometrical or plant patterns just like the sallamas.

The third stage in the arrangement of background surface is at the the corners, which are triangular empty spaces separating the main pattern from the border and forming obtuse angles with the longer and shorter sides of the carpet. The corner contours are made up of intertwined narrow bands called "SIzıs". The background colour of the corners decorated at all times with plant patterns is dark blue. Finally, the composition of the background is completed with a medallion pattern which is used in all Taşpınars with the exception of prayer rugs called "Göbek". The Taşpınar, creating an impression of depth and emitting a call for the infinity, shows that it has not deviated from the general characteristic of the Turkish art gfrace to the effect that it so creates.

2) In connection with the carpet and rug world of your province, have scientific studies been made in form of books, aerticles and encyclopedic entries and what are their bibliographic data if they are made?

In connection with the carpet and rug world of our province, see:

KONYALI, Ibrahim H., "Taşpınar Tarihi", Abideleri ve Kitabeleri ile Niğde Aksaray Tarihi, Ankara 1974, p. 2088.

DENIZ, Bekir, Taşpınar Halıları Örnek Alınarak Kayseri ve Çevresinde Çağdaş Türk Halı Sanatı (Unpublished PhD thesis at the Faculty of Letters in Ankara University), İzmir 1981.

DENIZ, Bekir, "Aksaray Müzesi Halıları", III. Ulusal El Sanatları Sempozyumu Bildirileri, Izmir 23-25 November 1983, Izmir 1984, pp. 93 - 127.

DENiZ, Bekir, "Taşpınar Halıları", Sanat Dünyamız, 1982 , p. 25.

YETKIN, Şerare, Türk Halı Sanatı, Iş Bankası Kültür Yayınları, Istanbul 1974, p. 100.

GÜR, Zeynep, 19. Yüzyıldan Günümüze Taşpınar Halıları, Published MS thesis, 1982.

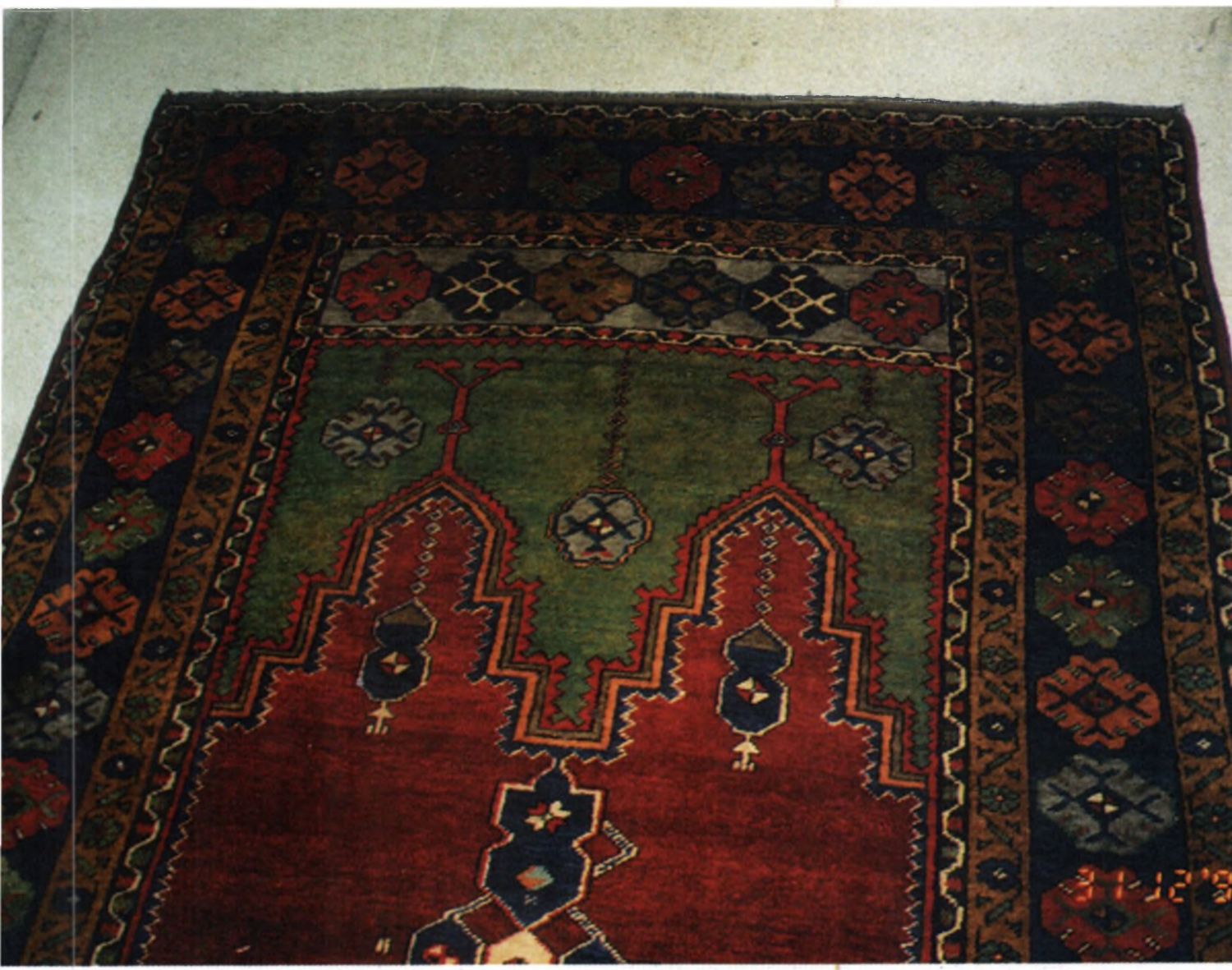

Resim/Picture 4

Yaklaşık

80 senelik

olduğu söylenen

bir Aksaray

Halısı

(Erdoğan-Pervin

Anbaş

Koleksiyonu)

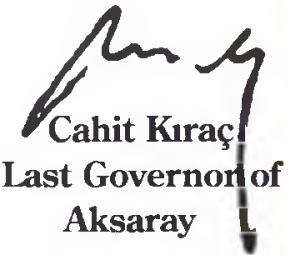

